\title{
Physico-Mechanical Analysis and Uvological Indices at Three Varieties of Grapes for Superior White Wines Grown in North-West Romania
}

\author{
Florin-Dumitru BORA ${ }^{1)}$, Tiberia Ioana POP ${ }^{1)}$, Claudiu-Ioan BUNEA ${ }^{1)}$, Anca PETER ${ }^{2)}$, Camelia NICULA ${ }^{2)}$, \\ Delia Elena URCAN ${ }^{1)}$, Anca BABEȘ ${ }^{11}$, Nastasia POP ${ }^{1 *}$ \\ 1) Faculty of Horticulture, USAMV Cluj-Napoca. ${ }^{2)}$ Technical University of Cluj-Napoca, Baia Mare Univer- \\ sity Centre \\ ${ }^{*}$ Corresponding author, e-mail: nastpop@yahoo.com
}

Bulletin UASVM Horticulture 71(2) / 2014

Print ISSN 1843-5254, Electronic ISSN 1843-5394

DOI:10.15835/buasvmcn-hort:10538

\begin{abstract}
The mechanical composition of the grapes is expressed by numerical ratio between the structural elements of the cluster (uvologic units): clusters, skins, pulp and seeds. The research in this paper aims the mechanical structure and uvologic values of three grape varieties for superior white wines: 'Fetească albă', 'Fetească regală' and 'Riesling italian', cultivated in NW Romania in 2013. The highest weight of a grape was recorded in the 'Fetească albă' variety cultivated in Şimleul Silvaniei $(135 \mathrm{~g})$ and the lowest was recorded in Fetească regală, in Baia Mare (91 g). The lowest index structure was recorded in 'Fetească albă' in Turulung Vii (21.54) and the higher was registered in 'Fetească regală' (36.69) in Şimleul Silvaniei area.
\end{abstract}

Keywords: grape indices, physico-mechanical analysis, white grapes varieties

\section{Introduction}

Uvology is the science that deals with the study of grapes as raw material in manufacturing and exploitation of grapes. By knowing the ampelographic characteristics of varieties, uvology follows their specialization for their economical use in production, to obtain varied and high quality products (Lung, 2013). The mechanical composition of the grapes is expressed in weight and numerical ratios between the elements of grape structure, uvologic units: clusters, skins, pulp and seeds (Mureșan, 2008).

\section{Material and Methods}

The biological material was represented by: 'Fetească albă', 'Fetească regală' and 'Riesling italian' from three different areas of NW Romania: Baia Mare (BM), Şimleul Silvaniei (SS) and Turulung Vii (TUR). Determinations were made on the mechanical structure of the clusters (the average weight of a grape, the number and weight of grapes per $1 \mathrm{~kg}$ of grapes, the average weight of a grape, rachis weight, peel, seed and their number, must yield) and the uvologic index were determined (structure index, grape and grape composition) using the formulas: structure index=grain weight/ weight of bunches, berries index $=$ no. grapes $/ 100$ g grapes, composition index=weight of pulp/peel + seed weight.

\section{Results and Discussion}

Knowledge of the mechanical structure of the grapes is important to characterize the technological potential of varieties of vines, calculating yield must, but also to determine the ability of different types of wine for fermentation (Lung, 2013). The highest value of grapes weight was achieved in 'Fetească albă' in Şimleul Silvaniei (135g) and the lowest weight was recorded in 'Fetească regală' (91g in Baia Mare, $97.9 \mathrm{~g}$ Şimleul Silvaniei) (Tab. 1). The variety with the highest average weight of a grape was 'Fetească regală' $(1.90 \mathrm{~g})$ and 'Riesling italian' has the smallest grapes in all three areas (between 1.21-1.31 g). The best yield in must was obtained in 'Fetească regală' (83.50\%), cultivated in Șimleul Silvaniei. 
Tab. 1. Physico-mechanical composition of the varieties studied / $1 \mathrm{~kg}$ grapes

\begin{tabular}{|c|c|c|c|c|c|c|c|c|c|c|c|}
\hline \multirow{2}{*}{ 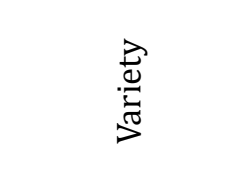 } & \multirow{2}{*}{ 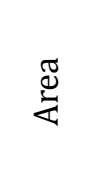 } & \multirow{2}{*}{$\begin{array}{c}\text { Average } \\
\text { weight of a } \\
\text { grape bunch } \\
\text { (g) }\end{array}$} & \multicolumn{2}{|c|}{ Berries } & \multirow{2}{*}{$\begin{array}{l}\text { Average } \\
\text { weight of } \\
\text { aberries } \\
\text { (g) }\end{array}$} & \multirow{2}{*}{$\begin{array}{l}\text { Skins } \\
\text { (g) }\end{array}$} & \multicolumn{2}{|c|}{ Seeds } & \multirow{2}{*}{$\begin{array}{l}\text { Rachis } \\
\text { (g) }\end{array}$} & \multirow{2}{*}{$\begin{array}{l}\text { Pulp } \\
\text { (g) }\end{array}$} & \multirow{2}{*}{$\begin{array}{l}\text { Yield } \\
\text { Must } \\
(\%)\end{array}$} \\
\hline & & & $\mathrm{Nr}$. & (g) & & & $\mathrm{Nr}$. & (g) & & & \\
\hline \multirow{3}{*}{ 'Fetească albă' } & $\mathrm{BM}$ & 122 & 622 & 964 & 1.54 & 141 & 563 & 45 & 36.4 & 778 & 80.70 \\
\hline & ȘS & 135 & 749 & 972 & 1.29 & 149 & 558 & 51.3 & 28.1 & 775 & 79.73 \\
\hline & TUR & 124 & 683 & 949 & 1.38 & 138 & 571 & 48.1 & 43.9 & 760 & 80.08 \\
\hline \multirow{3}{*}{$\begin{array}{l}\text { 'Fetească } \\
\text { regală' }\end{array}$} & BM & 91 & 502 & 957 & 1.90 & 133 & 675 & 37.2 & 40.7 & 787 & 82.23 \\
\hline & ȘS & 97.9 & 534 & 976 & 1.82 & 121 & 704 & 40.3 & 26.6 & 815 & 83.50 \\
\hline & TUR & 102.5 & 513 & 971 & 1.89 & 124 & 710 & 38.7 & 30.1 & 790 & 81.31 \\
\hline \multirow{3}{*}{ 'Riesling italian' } & BM & 118 & 786 & 953 & 1.21 & 164 & 867 & 48.1 & 47.3 & 740 & 77.64 \\
\hline & ȘS & 125 & 731 & 964 & 1.31 & 159 & 913 & 51 & 36.8 & 751 & 77.90 \\
\hline & TUR & 131.3 & 759 & 970 & 1.27 & 143 & 849 & 47 & 30.0 & 780 & 80.41 \\
\hline
\end{tabular}

Tab. 2. Grape index of the wine grape varieties

\begin{tabular}{llccc}
\hline Variety & \multicolumn{1}{c}{ Area } & $\begin{array}{c}\text { Structure index } \\
\text { of bunch grape }\end{array}$ & $\begin{array}{c}\text { Berries } \\
\text { index }\end{array}$ & $\begin{array}{c}\text { Berries } \\
\text { composition } \\
\text { index }\end{array}$ \\
\hline \multirow{3}{*}{ 'Feteasca albă' } & Baia Mare & 26 & 65 & 4 \\
& Șimleul Silvaniei & 35 & 77 & 4 \\
& Turulung Vii & 22 & 73 & 4 \\
\hline \multirow{3}{*}{ 'Feteasca regală' } & Baia Mare & 24 & 52 & 5 \\
& Șimleul Silvaniei & 37 & 55 & 5 \\
& Turulung Vii & 32 & 53 & 5 \\
\hline \multirow{3}{*}{ 'Riesling italian' } & Baia Mare & 20 & 82 & 3 \\
& Șimleul Silvaniei & 27 & 76 & 4 \\
& Turulung Vii & 32 & 78 & 4 \\
\hline
\end{tabular}

The lowest index structure of the grape was recorded in 'Fetească albă' in 'Turulung Vii' (22), while 'Fetească regală' registered the highest values in all areas: Şimleul Silvaniei (37), 'Turulung Vii' (32) and Baia Mare (24) (Tab.2). Of the three grape varieties studied, 'Riesling italian' has the highest grape index values for the three areas of culture: 82 in Baia Mare, 76 in Șimleul Silvaniei and 78 in 'Turulung Vii' and the lowest grain index was achieved in 'Fetească regală' in the three areas studied (52-55). When analyzing the composition index of grapes it can be observed the lowest index was achieved in the 'Riesling italian' variety (3-4).

Conclusion. Regarding the mechanical analysis, 'Fetească regală' has the highest grape weight, pulp weight and best must yield compared with 'Fetească albă' and 'Riesling italian' in all three areas. The uvologic index for the analyzed varieties are within the specific intervals for varieties for white wines of superior quality.

Acknowledgements. This paper was published under the frame of European Social Fund, Human Resources Development Operational Programme 2007-2013, projectno. POSDRU/159/1.5/S/132765.

\section{REFERENCES}

1. Mureșan C (2008). Wine Technology -Applications Practice-. Ed. Universității Aurel Vlaicu. Arad.

2. Lung ML (2013). Researches regarding the content in substances with antioxidant effect, at some vine varieties from different culture areas of Romania. PhD Thesis. Cluj-Napoca. 